ORIGINAL ARTICLE

\title{
Cancer risk for chemical workers exposed to 2,3,7,8-tetrachlorodibenzo-p-dioxin
}

\author{
K M Bodner, J J Collins, L J Bloemen, M L Carson
}

Occup Environ Med 2003;60:672-675

See end of article for authors' affiliations

Correspondence to:

K M Bodner, The Dow

Chemical Company,

1803 Building Midland,

MI 48674, USA;

kbodner@dow.com

Accepted 25 September 2002

\begin{abstract}
Aims: To describe the long term mortality experience of a cohort of 2187 male chemical production workers previously exposed to substantial levels of dioxin.

Methods: Vital status for a previously identified cohort was determined for an additional 10 years, to 1995. Dioxin exposures took place before 1983 and were sufficient to result in chloracne in 245 individuals. Mortality rates were compared with national figures and with a large pool of co-workers in unrelated production jobs.

Results: All cancers combined (standardised mortality ratio $(S M R)=1.0,95 \% \mathrm{Cl} 0.8$ to 1.1 ) and lung cancer (SMR $=0.8,95 \% \mathrm{Cl} 0.6$ to 1.1 ) were at or below expected levels. Rates for soft tissue sarcoma (SMR $=2.4,95 \% \mathrm{Cl} 0.3$ to 8.6$)$ and non-Hodgkin's lymphoma $(\mathrm{SMR}=1.4,95 \% \mathrm{Cl} 0.6$ to 2.7 ) were greater than expected overall, but below expectation in the update period. No trend of increasing risk with increasing exposure was observed for these cancers. Workers who developed chloracne had very low all-cancer rates $(S M R=0.5,95 \% \mathrm{Cl} 0.3$ to 1.0$)$, and lung cancer rates $(S M R=0.3,95 \% \mathrm{Cl} 0.0$ to 1.11 .

Conclusions: We found no coherent evidence of increased cancer risk from dioxin exposure in this cohort. Our study highlights the wide range of cancer rates and the lack of consistency across dioxin studies.
\end{abstract}

$\mathrm{R}$ ecently, the International Agency for Research on Cancer (IARC) classified 2,3,7,8-tetrachlorodibenzo-p-dioxin (TCDD) as a proven human carcinogen, based on animal studies and mechanistic information. However, the epidemiology evidence on carcinogenicity was determined to be limited. ${ }^{1}$ Increased risk of lung cancer, non-Hodgkin's lymphoma (NHL), soft tissue sarcoma (STS), and all cancers combined were observed in some but not all studies of persons with substantial dioxin exposures. ${ }^{2-5}$

We report on the third update of the mortality experience of 2187 Dow Chemical Company workers who were likely exposed to substantial levels of dioxin. Exposure determinations were developed through industrial hygiene monitoring and analysis of historical plant operations, combined with complete detailed work histories of all cohort members. For many subjects, diagnosed cases of chloracne could be traced directly to particular high exposure incidents; hence, we believe the degree of exposure within the cohort in general is corroborated by the 245 or more documented reports of chloracne..$^{6-9}$

Main messages

- When follow up of the Dow Chemical Company cohort of 2187 male dioxin exposed workers was extended an additional 10 years, mortality from all cancers combined occurred at background levels, but lung cancer deaths were $20 \%$ fewer than expected

- No additional deaths from soft tissue sarcoma occurred, and non-Hodgkin's lymphoma mortality declined.

- There was no coherent evidence of a link between dioxin and cancer(s) in this cohort.

- The diversity of outcomes among this study, other published research, and the cohorts contributing to the NIOSH Dioxin Registry and the IARC multinational study suggests that no single agent is likely to be the cause of all the cancers commonly attributed to dioxins.
Most of the workers in our study are also included in both the IARC International Study and the NIOSH Dioxin Registry, contributing $45 \%$ of the person-years of the latter. ${ }^{2}$ Aside from being the largest component, the Dow cohort has the longest follow up (that is, a maximum of 55 years) of any plant study group in either of these combined studies. The current update provides an opportunity to examine the consistency of findings from multi-plant studies by NIOSH and IARC with our study group.

\section{MATERIALS AND METHODS}

Details of worker selection and exposure classification have been described elsewhere. ${ }^{9}$ Briefly, work records were used to identify 2187 males who had worked in any of the production areas with potential dioxin exposure. All of the production units involved had ceased operations prior to 1983. Five female workers were excluded from analyses. All of the females were alive at the close of the study; one was retired, while the other four were still active employees. Descriptions of tasks performed in each of 500-plus jobs with potential exposure were drafted. Vapour phase chromatography provided estimates of TCDD concentrations in process streams and intermediate or end products from five production areas, as summarised by Ott and colleagues. ${ }^{9}$ Additionally, 2282 rabbit ear bioassays for chloracnegenic response were conducted. Each job title was assigned a TCDD exposure score of $0-4$ based on the above data, industrial hygiene monitoring, description of job duties, process flow diagrams, and assessment of major production process changes. An increase

Abbreviations: $\mathrm{Cl}$, confidence interval; IARC, International Agency for Research on Cancer; ICDA-8, eighth revision (adapted) of the international classification of disease; NHL, non-Hodgkin's lymphoma; $\mathrm{NIOSH}$, National Institute for Occupational Safety and Health; RR, relative risk; SMR, standardised mortality ratio; STS, soft tissue sarcoma; TCDD, 2,3,7,8-tetrachlorodibenzo-p-dioxin 
Table 1 Selected results from four mortality studies of the Dow dioxin cohort

\begin{tabular}{|c|c|c|c|c|}
\hline & \multicolumn{4}{|c|}{ Authors and year of publication } \\
\hline & Cook et al, $1986^{7}$ & $\begin{array}{l}\text { Cook et al, } 1987^{8} \\
\text { Ott et al, } 1987^{9}\end{array}$ & Bond et al, $1989^{\circ}$ & Current study \\
\hline Years of follow up & 1940-79 & 1940-82 & $1940-84$ & $1940-94$ \\
\hline Number of workers & 2189 & 2187 & 2192 & 2187 \\
\hline$\%$ deceased & 14 & 17 & 19 & 30 \\
\hline $\begin{array}{l}\text { Cause of death } \\
\text { (ICDA-8 rubric) }\end{array}$ & SMR $(95 \%$ CI) [obs/exp] & SMR $(95 \%$ CI) [obs/exp] & SMR $(95 \%$ CI) [obs/exp] & SMR $(95 \%$ CI) [obs/exp] \\
\hline All causes (001-999) & 0.9 (0.8 to 1.0 ) [298/327.5] & 0.9 (0.8 to 1.0 ) [370/396.0] & $0.9(0.8$ to 1.0$)[406 / 441.3]$ & 0.9 (0.8 to 1.0$)[655 / 721.1]$ \\
\hline All cancer (140-209) & $1.0(0.7$ to 1.2$)[61 / 63.5]$ & $1.0(0.8$ to 1.3$)[81 / 79.3]$ & $1.0(0.8$ to 1.3$)[95 / 92.2]$ & $1.0(0.8$ to 1.1$)[168 / 170.4]$ \\
\hline Lung cancer (162) & $0.8(0.5$ to 1.3$)[18 / 22.0]$ & 0.8 (0.5 to 1.2$)[23 / 27.9]$ & $0.9(0.6$ to 1.2$)[28 / 33.0]$ & 0.8 (0.6 to 1.1$)[54 / 62.5]$ \\
\hline Soft tissue sarcoma (171) & $3.3(0.1$ to 18.6$)[1 / 0.3]$ & $2.5(0.1$ to 13.9$)[1 / 0.4]$ & $5.0(0.6$ to 18.1$)[2 / 0.4]$ & $2.4(0.3$ to 8.6$)[2 / 0.8]$ \\
\hline $\begin{array}{l}\text { Non-Hodgkin's lymphoma } \\
(200,202)\end{array}$ & $2.3(0.8$ to 5.6$)[5 / 2.1]$ & $1.9(0.6$ to 4.5$)[5 / 2.6]$ & $2.1 \quad(0.8$ to 4.5$)[6 / 2.9]$ & $1.4(0.6$ to 2.7$)[8 / 5.8]$ \\
\hline All remaining cancers & $0.9(0.7$ to 1.3$)[37 / 39.1]$ & $1.1(0.8$ to 1.4$)[52 / 48.4]$ & $1.1(0.8$ to 1.4$)[59 / 56.1]$ & 1.0 (0.8 to 1.2$)[104 / 101.3]$ \\
\hline
\end{tabular}

in one score unit was considered equivalent to a tenfold relative increase in TCDD exposure intensity. Biomonitoring data were not available for this cohort. Diagnoses of chloracne were made through a multilevel review of company medical records. ${ }^{10}$

Person-years at risk for mortality were accumulated for each subject, beginning on the date he first worked in a job with potential exposure to dioxins, but no earlier than 1940. For the analyses of chloracne diagnosed workers, person-years were counted from the date of diagnosis. Vital status was followed until the end of the study period, 31 December 1994. Follow up was $100 \%$ complete and death certificates were obtained for all decedents. A certified nosologist coded the cause of death.

We used a modified life table program to calculate standardised mortality ratio (SMR) risk estimates and 95\% confidence intervals (CI) relative to the US white male population. ${ }^{11}$ A Mantel-Haenszel procedure was used to test mortality differences among cumulative exposure categories. ${ }^{12}$ A large pool of local workers with no experience in the targeted departments and who presumably had only background exposure to dioxin served as a baseline reference. Linear trends in mortality across exposure groups were tested by Mantel's single degree of freedom $\chi^{2}$ procedure. ${ }^{13}$ Internal analyses were stratified by age, calendar year, and hourly/ salary status.

\section{RESULTS}

Table 1 presents the original study findings of Cook et al and the three updates. ${ }^{6-9}$ We added 15 years of follow up to the original study and 10 years to the last update. While results of the original study were based on 61 cancer deaths, the current update examined 168 deaths from cancer. As in previous studies of these workers, total mortality in the most recent update was less than expected ( SMR $=0.9,95 \%$ CI 0.8 to 1.0 ). All cancers combined ( $\mathrm{SMR}=1.0,95 \% \mathrm{CI} 0.8$ to 1.1 ) and lung cancer $(\mathrm{SMR}=0.8,95 \% \mathrm{CI} 0.6$ to 1.1$)$ were at or below expected levels, but STS ( SMR $=2.495 \%$ CI 0.3 to 8.6 ) and NHL $($ SMR $=1.4,95 \%$ CI 0.6 to 2.7 ) were greater than expected. No STS deaths occurred in the most recent update period, thus reducing the relative risk from 5.0 in the Bond et al study to 2.4 in the present study. Since 1984, two additional deaths from NHL occurred, whereas 2.9 were expected. Risk estimates for stomach cancer ( SMR $=1.5,95 \%$ CI 0.7 to 2.7 ) and prostate cancer $(\mathrm{SMR}=1.7,95 \% \mathrm{CI} 1.0$ to 2.6$)$ were greater than 1.0, while those for bladder cancer ( $S M R=0.7$, 95\% CI 0.1 to 2.0 ) and cancer of the brain and other central nervous system ( $\mathrm{SMR}=0.6,95 \%$ CI 0.1 to 1.8 ) were less than 1.0 (not shown). Applying a 25 year induction-latency period to the analyses did not appreciably change the findings (not shown).
The 245 workers with chloracne generally had lower death rates than the comparison group (not shown). The SMR for all causes was 0.7 (95\% CI 0.5 to $0.9,51$ observed), all cancers was 0.5 (95\% CI 0.3 to 1.0, 10 observed), lung cancer was 0.3 (95\% CI 0.0 to 1.1, two observed), STS was 10.9 (95\% CI 0.3 to 61.9 , one observed), and non-Hodgkin's lymphoma was 0.0 (95\% CI 0.0 to $5.7,0.7$ expected).

Table 2 shows mortality analyses by cumulative exposure categories, using internal and external comparison groups. There were no linear trends observed for any of the cancers. Workers with very high dioxin exposure had more observed than expected cancer deaths (relative risk $(\mathrm{RR})=1.4,95 \% \mathrm{CI}$ 0.9 to 2.0 ) and deaths from STS ( $R R=15.8,95 \%$ CI 5.2 to 47.8 , two cases), but most other exposure categories for these cancer deaths had relative risks at or below 1.0. There were fewer lung cancer deaths than expected in the higher exposure categories, with a relative risk of 0.7 (95\% CI 0.3 to 1.8 ) in the highest group. There were only small differences in risk estimates between internal or external comparisons.

\section{DISCUSSION}

Several characteristics contribute to the importance of this cohort. We traced 2187 workers with complete follow up and job histories for an average of 30 years. Although biomonitoring data were not available, Dow's analytical and industrial hygiene data were the most comprehensive of any in the NIOSH Dioxin Registry or the International Dioxin Study. ${ }^{9}$ High dioxin exposures were corroborated by clinically confirmed chloracne documented among $11 \%$ of the cohort.

Recent evaluations of dioxin workers have focused on total cancers, lung cancer, soft tissue sarcoma, and non-Hodgkin's lymphoma. Of these, increased risk of lung cancer is the most consistent finding in the studies with high exposure. ${ }^{1}$ However, we find lung cancer rates at or below expected levels among all dioxin workers as well as workers with chloracne, and we find no increased risk with increasing exposure. Both the IARC multination study and NIOSH Dioxin Registry report a wide range of lung cancer risks by plant site. ${ }^{15}{ }^{16}$ In the latter, SMRs for lung cancer vary from 0.7 to 2.4 , but the excess risk derives mainly from two of the 12 plants. ${ }^{17}$ Risk estimates in the IARC Registry ranged from 0.0 to 3.0. Other reports also provide mixed results for various groups of workers. ${ }^{5}{ }^{18}$ Although sampling variation is a possible explanation for the wide range of SMRs, potential confounding at the plants with high SMRs is another possibility often mentioned. Due to the unavailability of data on tobacco use, no adjustment for smoking behaviours was made in the Dow cohort. However, since for internal comparisons both exposed and unexposed workers were drawn from a geographically and socioeconomically uniform population, confounding by smoking or other factors is likely not appreciable. 
Table 2 Observed deaths (Obs), expected deaths (Exp), relative risks (RR) stratified by age, calendar year, and pay status, and standardised mortality ratios (SMR) for selected causes among male employees with likely exposure to higher chlorinated dioxins, compared to unexposed plant workers and the US population

\begin{tabular}{|c|c|c|c|c|c|c|c|}
\hline \multirow{2}{*}{$\begin{array}{l}\text { Cause of death } \\
\text { (ICDA-8), Exposure } \\
\text { category }\end{array}$} & \multirow[b]{2}{*}{ Obs } & \multicolumn{3}{|l|}{ RR } & \multicolumn{3}{|l|}{ SMR } \\
\hline & & $\operatorname{Exp}$ & $\mathrm{RR}$ & $95 \% \mathrm{Cl}$ & $\operatorname{Exp}$ & SMR & $95 \% \mathrm{Cl}$ \\
\hline \multicolumn{8}{|c|}{ All malignant neoplasms (140-209) } \\
\hline Background & 2489 & & 1.0 & & 2649.1 & 0.9 & 0.9 to 1.0 \\
\hline Very low & 19 & 18.8 & 1.0 & 0.6 to 1.6 & 20.6 & 0.9 & 0.6 to 1.4 \\
\hline Low & 44 & 42.0 & 1.0 & 0.8 to 1.4 & 46.0 & 1.0 & 0.7 to 1.3 \\
\hline Moderate & 52 & 47.7 & 1.1 & 0.8 to 1.4 & 51.4 & 1.0 & 0.8 to 1.3 \\
\hline High & 27 & 29.5 & 0.9 & 0.6 to 1.3 & 31.7 & 0.9 & 0.6 to 1.2 \\
\hline $\begin{array}{l}\text { Very high } \\
\text { p value for linear trend }\end{array}$ & 26 & 19.2 & $\begin{array}{l}1.4 \\
0.33\end{array}$ & 0.9 to 2.0 & 20.8 & 1.3 & 0.8 to 1.8 \\
\hline \multicolumn{8}{|l|}{ Cancer of the lung (162) } \\
\hline Background & 843 & & 1.0 & & 893.0 & 0.9 & 0.9 to 1.0 \\
\hline Very low & 4 & 6.5 & 0.6 & 0.2 to 1.6 & 7.2 & 0.6 & 0.2 to 1.4 \\
\hline Low & 18 & 14.6 & 1.2 & 0.8 to 2.0 & 16.2 & 1.1 & 0.7 to 1.7 \\
\hline Moderate & 15 & 16.3 & 0.9 & 0.6 to 1.5 & 17.7 & 0.9 & 0.5 to 1.4 \\
\hline High & 6 & 10.4 & 0.6 & 0.3 to 1.3 & 11.2 & 0.5 & 0.2 to 1.2 \\
\hline Very high & 5 & 6.8 & 0.7 & 0.3 to 1.8 & 7.4 & 0.7 & 0.2 to 1.6 \\
\hline$p$ value for linear trend & & & 0.27 & & & & \\
\hline \multicolumn{8}{|l|}{ Soft tissue sarcoma (171) } \\
\hline Background & 18 & & 1.0 & & 11.8 & 1.5 & 0.9 to 2.4 \\
\hline Very low & 0 & 0.2 & 0.0 & NA & 0.1 & 0.0 & 0.0 to 33.5 \\
\hline Low & 0 & 0.4 & 0.0 & NA & 0.3 & 0.0 & 0.0 to 14.8 \\
\hline Moderate & 0 & 0.4 & 0.0 & NA & 0.3 & 0.0 & 0.0 to 14.8 \\
\hline High & 0 & 0.2 & 0.0 & NA & 0.1 & 0.0 & 0.0 to 26.3 \\
\hline $\begin{array}{l}\text { Very high } \\
\text { p value for linear trend }\end{array}$ & 2 & 0.1 & $\begin{array}{l}15.8 \\
0.07\end{array}$ & 5.2 to 47.8 & 0.1 & 21.8 & 2.7 to 80.2 \\
\hline \multicolumn{8}{|c|}{ Non-Hodgkin's lymphoma $(200,202)$} \\
\hline Background & 82 & & 1.0 & & 84.7 & 1.0 & 0.8 to 1.2 \\
\hline Very low & 2 & 0.7 & 3.1 & 0.8 to 11.6 & 0.7 & 2.8 & 0.3 to 10.0 \\
\hline Low & 1 & 1.4 & 0.7 & 0.1 to 4.9 & 1.6 & 0.6 & 0.0 to 3.4 \\
\hline Moderate & 2 & 1.7 & 1.2 & 0.3 to 4.9 & 1.7 & 1.2 & 0.1 to 4.2 \\
\hline High & 2 & 1.0 & 2.1 & 0.5 to 8.3 & 1.1 & 1.9 & 0.2 to 6.9 \\
\hline $\begin{array}{l}\text { Very high } \\
\text { p value for linear trend }\end{array}$ & 1 & 0.6 & $\begin{array}{l}1.7 \\
0.31\end{array}$ & 0.2 to 11.9 & 0.7 & 1.5 & 0.0 to 8.3 \\
\hline
\end{tabular}

In the previous update of the Dow cohort, STS was cited as the underlying cause on death certificates of two subjects, but no additional cases were ascertained in the current update. Although there was a single case of STS among workers with chloracne, this case was in fact confirmed by pathologists to be a renal clear cell carcinoma. Soft tissue sarcomas ascertained from death certificates are subject to serious misclassification error, although differential misclassification among exposed and referent populations seems unlikely. ${ }^{19-21}$ Nevertheless, reclassification of few cases of an uncommon cancer could have a profound impact on the overall STS risk estimates among dioxin exposed persons. Reports cite four instances of STS misclassification among workers in the NIOSH registry. ${ }^{17}$ Additionally, this outcome is inconsistent within the registry. Only one other of the 12 component subcohorts contributed cases to the overall total of four STS cases diagnosed on death certificates of exposed workers.

We found a slight increase in non-Hodgkin's lymphoma in our study, similar to net risk estimates reported by $\mathrm{NIOSH}^{17}$ and IARC. ${ }^{3}$ However, the relative risk was not related to exposure level, and was imprecise. There were no non-Hodgkin's lymphoma deaths among chloracne diagnosed workers, though only 0.7 were expected. This cohort contributed seven of the 10 cases of NHL reported by NIOSH, ${ }^{17}$ while three additional cohorts reported one case each. The lack of consistency across studies and our equivocal findings caution against a causal interpretation for this finding.

Mortality from prostate cancer remained moderately increased as in previous reports. ${ }^{9}$ It was also slightly increased in the NIOSH and IARC registries, ${ }^{3}{ }^{17}$ although IARC showed no difference between TCDD exposed and unexposed workers (1.11, 1.10, respectively). The degree to which these findings were influenced by the Dow cohort was not stated. Results of other studies were mixed. ${ }^{422}$ Because of high background incidence of prostate cancer in the general population, inconsistency of diagnosis, and the strong influence of competing risks, the evidence for an occupational aetiology for prostate cancer is not compelling.

We observed cancer deaths at expected levels for the entire cohort (168 observed, 170.4 expected), but observed deaths exceeded expected deaths only in the highest cumulative exposure group (26 observed, 19.9 expected), without evidence of a trend. Workers with chloracne had a 50\% deficit for all cancers combined. Many studies of highly exposed dioxin workers and 8 of 12 NIOSH subcohorts report a small increase in risk for all malignant neoplasms combined, but no particular cancer site has been consistently prominent across studies. A causal relation of this nature would be very unusual in occupational studies since all known carcinogens precipitate one or more cancers of specific types. Some have suggested that dioxin may be a generalised carcinogenic agent which may act as a tumour promoter at multiple sites by increasing cell proliferation or inhibiting apoptosis. ${ }^{24}$ This, however, does not explain the lack of specificity seen across cohorts. Others have proposed that confounding exposures could be producing the all cancer increased risk in the dioxin cohorts. ${ }^{25}$ Given the wide range of site specific cancer risks among persons with high dioxin exposures, a single agent 
aetiology seems unlikely, and we favour the later hypothesis. We also agree with IARC that the findings must be treated with caution. ${ }^{13}$

The past diagnoses of two STS cases among workers with the highest dioxin exposures is a singular occurrence that has not been clarified by our own data or other current research. The uncertainties surrounding this ill defined outcome argue for caution in assessing its aetiology. Despite some unanswered questions, we find no coherent evidence that this cohort has an increased risk of cancer collectively, or of any particular type of cancer that can be attributed to dioxin exposure. Our findings from the largest single study group in the NIOSH and IARC multi-plant studies also highlight the wide range of cancer rates across individual dioxin studies and the heterogeneity of findings within these multi-plant investigations.

\section{Authors' affiliations}

K M Bodner, J J Collins, L J Bloemen, M L Carson, The Dow

Chemical Company, USA

\section{REFERENCES}

1 International Agency for Research on Cancer. IARC Monographs on the evaluation of the carcinogenic risk of chemicals to humans. Polychlorinated dibenzo-para-dioxins and polychlorinated dibenzofurans. IARC Monographs Volume 69. Lyon: IARC, 1997.

2 Steenland K, Piacitelli L, Deddens J, et al. Cancer, heart disease, and diabetes in workers exposed to 2,3,7,8-tetrachlorodibenzo-p-dioxin. J Natl Cancer Inst 1999;91:779-86.

3 Kogevinas $M$, Becher $\mathrm{H}$, Benn T, et al. Cancer mortality in workers exposed to phenoxy herbicides, chlorophenols, and dioxins. Am J Epidemiol 1997;145:1061-75.

4 Ott MG, Zober A. Cause specific mortality and cancer incidence among employees exposed to 2,3,7,8-TCDD after a 1953 reactor accident. Occup Environ Med 1996;53:606-12.

5 Bertazzi PA, Consonni D, Bachetti S, et al. Health effects of dioxin exposure: a 20-year mortality study. Am J Epidemiol 2001;153:103144.

6 Bond GG, McLaren EA, Lipps TE, et al. Update of mortality among chemical workers with potential exposure to the higher chlorinated dioxins. J Occup Med 1989;31:121-3.

7 Cook RR, Bond GG, Olson RA, et al. Evaluation of the mortality experience of workers exposed to the chlorinated dioxins. Chemosphere 1986;15:1769-76.

8 Cook RR, Bond GG, Olson RA, et al. Update of the mortality experience of workers exposed to chlorinated dioxins. Chemosphere 1987; 16:2111-16.
9 Ott MG, Olsen RA, Cook RR, et al. Cohort mortality study of chemical workers with potential exposure to the higher chlorinated dioxins. J Occup Med 1987;29:422-9.

10 Bond GG, McLaren EA, Brenner FE, et al. Incidence of chloracne among chemical workers potentially exposed to chlorinated dioxins. J Occup Med 1989;31:771-4.

11 Marsh GM, Youk AO, Stone RA, et al. OCMAP-Plus: a program for the comprehensive analysis of occupational cohort data. J Occup Environ Med 1998;40:351-6.

12 Hakulinen T. A Mantel-Haenszel statistic for testing the association between a polychotomous exposure and a rare outcome. Am J Epidemiol 1981;113:192-6.

13 Mantel N. Chi-square tests with one degree of freedom; extensions of the Mantel-Haenszel procedure. J Am Stat Assoc 1963;58:690-700.

14 Piacitelli L, Marlow D, Fingerhut $M$, et al. A retrospective job exposure matrix for estimating exposure to 2,3,7,8-tetrachlorodibenzo-p-dioxin. Am J Ind Med 2000;38:28-39

15 Collins JJ, Acquavella JF, Friedlander BR. Reconciling old and new findings on dioxin. Epidemiology 1992;3:65-8.

16 Kogevinas M, Winkelmann R, Saracci R, et al. Cancer mortality in an international cohort of workers exposed to chlorophenoxy herbicides, chlorophenols and contaminants. IARC Internal Report 92/002. Lyon: IARC, 1992.

17 Fingerhut MA, Halperin WE, Marlow DA, et al. Cancer mortality in workers exposed to 2,3,7,8-tetrachlorodibenzo-p-dioxin. N Engl J Med $1991 ; 324: 212-18$.

18 Ott MG, Messerer P, Zober MA. Assessment of past occupational exposure to TCDD using blood lipid analyses. Int Arch Occup Environ Health 1993;65:1-8.

19 Fingerhut MA, Halperin WE, Honchar PA, et al. Review of exposure and pathology data for seven cases reported as soft tissue sarcoma among persons occupationally exposed to dioxin-contaminated herbicides. In: Lowrance WW, ed. Public health risks of the dioxins. Proceedings of a symposium held 19-20 October 1983, Rockefeller University, New York. Los Altos, CA: Wm Kaufmann, 1984:187-203.

20 Suruda AJ, Ward EM, Fingerhut MA. Identification of soft tissue sarcoma deaths in cohorts exposed to dioxin and to chlorinated naphthalenes. Epidemiology 1993;4:14-19.

21 Bond GG, Cook RR, Brenner FE, et al. Evaluation of mortality patterns among chemical workers with chloracne. Chemosphere 1987:16:2117-21.

22 Becher H, Flesch-Janys D, Kaupinen T, et al. Cancer mortality in German male workers exposed to phenoxy herbicides and dioxins. Cancer Causes Control 1996;7:312-21.

23 Bertazzi PA, Zocchetti C, Guercilena S, et al. Dioxin exposure and cancer risk: a 15-year mortality study after the "Seveso accident". Epidemiology 1997;8:646-52.

24 Samet JM. Dioxin and cancer: the never-ending story. Cancer Causes Control 1996;7:302-3

25 Smith AH, Lopipero P. Invited commentary: How do the Seveso findings affect conclusions concerning TCDD as a human carcinogen? Am J Epidemiol 2001;153:1045-7. 